\title{
Thermophilic biological nitrogen removal in industrial wastewater treatment
}

\author{
C.M. Lopez-Vazquez ${ }^{\mathrm{a},{ }^{*}}$, M. Kubare ${ }^{\mathrm{a}}$, D.P. Saroj ${ }^{\mathrm{b}}$, C. Chikamba ${ }^{\mathrm{a}}$, and D. Brdjanovic ${ }^{\mathrm{a}, \mathrm{c}}$ \\ a Environmental Engineering and Water Technology Department. \\ UNESCO-IHE Institute for Water Education. \\ Westvest 7, 2611 AX Delft, The Netherlands. \\ (E-mails: c.lopezvazquez@unesco-ihe.org,d.brdjanovic@unesco-ihe.org) \\ ${ }^{\mathrm{b}}$ Centre for Environmental Health Engineering (CEHE). \\ Faculty of Engineering and Physical Sciences, University of Surrey, \\ Surrey GU2 7XH, United Kingdom. \\ (E-mail:d.saroj@surrey.ac.uk) \\ ${ }^{c}$ Department of Biotechnology, Delft University of Technology. \\ Julianalaan 67, 2628 BC Delft, The Netherlands. \\ (E-mail:d.brdjanovic@tudelft.nl)
}

\begin{abstract}
Nitrification is an integral part of biological nitrogen removal processes and usually the limiting step in wastewater treatment systems. Since nitrification is often considered not feasible at temperatures higher than $40^{\circ} \mathrm{C}$, warm industrial effluents (with operating temperatures higher than $40^{\circ} \mathrm{C}$ ) need to be cooled down prior to biological treatment, increasing the energy and operating costs of the plants. This study describes the occurrence of thermophilic biological nitrogen removal activity (nitrititation, nitratation and denitrification) at a temperature as high as $50^{\circ} \mathrm{C}$ in an activated sludge wastewater treatment plant treating wastewater from an oil-refinery. The similar nitrititation and nitritatation rates observed between 35 and $50^{\circ} \mathrm{C}$ (of 3.3-4.6 $\mathrm{mgNH}_{4}{ }^{+}-\mathrm{N} / \mathrm{mgVSS}$.h and 2.9-4.5 $\mathrm{mgNO}_{2}{ }^{-} \mathrm{N} / \mathrm{mgVSS}^{-}$, respectively) led to nitrite accumulation. Using a modified 2-step nitrification-2-step denitrification mathematical model extended with the incorporation of double Arrhenius equations, the nitrification (nitrititation and nitratation) and denitrification activities were described including the cease in biomass activity at $55^{\circ} \mathrm{C}$. Fluorescence in situ Hybridization
\end{abstract}


(FISH) analyses revealed that Nitrosomonads and Nitrosomonas oligotropha (known ammonia-oxidizing organisms, $\mathrm{AOB}$ ) were present in the sludge. However, no nitrite oxidizing organisms (NOB) were observed using the FISH probes applied in this study. These observations suggest that thermophilic biological nitrogen removal can be attained in wastewater treatment systems. It opens the possibilities for the implementation of biological nitrogen removal processes via the $\mathrm{NO}_{2}{ }^{-} \mathrm{N}$ pathway in the main stream, which may further contribute to the optimization and even the re-engineering of wastewater treatment systems that treat warm wastewater streams.

\section{KEYWORDS}

Nitrification, higher temperature, Ammonia-Oxidizing Bacteria (AOB), Nitrite-Oxidizing Bacteria (NOB), industrial wastewater.

\section{INTRODUCTION}

The biological nitrogen removal (BNR) process via nitrification-denitrification in activated sludge wastewater treatment plants (WWTP) has proven to be an efficient technology to reduce the discharge of nitrogen compounds into surface water bodies. This contributes to keep the concentrations of the nitrogen compounds below toxic levels and avoid eutrophication. Originally developed to treat municipal wastewater in countries with cold and moderate climate (e.g. $10-20^{\circ} \mathrm{C}$ sewage temperature), the BNR process has also shown to be capable to treat warm industrial wastewater in activated sludge systems (at a temperature as high as $35-40^{\circ} \mathrm{C}$ ) from tanneries and oil-refineries (Moussa et al., 2004; and Pinzon-Pardo et al., 2007). The application of BNR at a higher temperature is usually successful because the optimal temperature for the nitrification process in activated sludge systems is between 35 and $38^{\circ} \mathrm{C}$ (Buswell et al., 1954; Laudelout and van Tichelen, 1960; Henze et al., 1995; Hellinga et 
al., 1998) with a maximum observed cardinal temperature at around $40^{\circ} \mathrm{C}$ (Henze et al., 1995). As a consequence, to avoid treatment process upsets and deterioration, the temperature of industrial effluents (often having temperatures substantially higher than $40^{\circ} \mathrm{C}$ ) is kept below $35-37^{\circ} \mathrm{C}$ by the application of heat-exchangers and cooling towers. This practice increases the operating costs and is associated with environmental impact due to the higher energy requirements, $\mathrm{CO}_{2}$ generation and higher water consumption.

As such, to achieve BNR within the thermophilic temperature interval (e.g. between 40 and $60^{\circ} \mathrm{C}$; Henze et al., 2008) may contribute to significant operational and environmental advantages (such as lesser energy requirements, lower water consumption and lower operating costs). It could also favor the nitritation process and lead to additional potential savings with regard to carbon and aeration requirements by performing nitrogen removal over nitrite (Hellinga et al., 1998). Though thermophilic nitrifying activity has been rarely documented in sewage treatment plants (Barrit, 1933; Hellinga et al., 1998), it is often observed in soil, leachate and solid waste treatment applications (Stark 1996; Choi and Eum, 2002; Berge et al., 2007; Maeda et al., 2010). Few recent works have attempted to study the effect of temperature on two-step nitrification by means of laboratory scale bioreactors fed on synthetic wastewater (Guo et al., 2010; Sudarno et al., 2011). However, the understanding of the effect of higher temperature on the performance of nitrifying species is limited.

This study describes the occurrence of BNR activity at a temperature as high as $50^{\circ} \mathrm{C}$ in an activated sludge plant treating wastewater from an oil refinery. The temperature dependencies of the BNR processes were determined through the execution of short-term (hours) batch experiments. A modified mathematical model was formulated to describe the biological nitrification and denitrification processes observed in the temperature range from 35 to $55^{\circ} \mathrm{C}$. 


\section{MATERIALS AND METHODS}

\section{Batch activity tests}

To assess the thermophilic BNR processes and their temperature dependency, a series of short-term (hours) batch activity tests were executed at 35, 40, 45, 50 and $55^{\circ} \mathrm{C}$ using fresh activated sludge from a WWTP treating oil refinery wastewater (Pinzon-Pardo et al., 2007). Currently, the oil refinery WWTP attains satisfactory biological organic matter and nitrogen removal at an average wastewater temperature of $34^{\circ} \mathrm{C}$ (effluent biochemical oxygen demand, $\mathrm{BOD}_{5}$, chemical oxygen demand, COD, and total nitrogen concentrations are lower than 25 , 125 and $10 \mathrm{mg} / \mathrm{L}$, respectively). The plant consists of three tanks in series; the first two operate in on-off aeration mode with pure oxygen supply for nitrogen removal, whilst methanol is dosed to support denitrification; and the third tank is kept constantly aerobic. Further details concerning the plant process scheme and operating conditions can be found elsewhere (Pinzon-Pardo et al., 2007).

For the execution of the short-term batch activity tests, mixed liquor activated sludge were collected at the oil refinery WWTP and stored at $4^{\circ} \mathrm{C}$ prior to the execution of the tests. The tests were executed within $24 \mathrm{~h}$ after sludge collection. The batch experiments were designed to assess the nitrification and denitrification activities of the sludge. To study nitrification as a two-step process, $10 \mathrm{mg} / \mathrm{L}$ of nitrite $\left(\mathrm{NO}_{2}-\mathrm{N}\right)$ and $20 \mathrm{mg} / \mathrm{L}$ of ammonia $\left(\mathrm{NH}_{4}-\mathrm{N}\right)$ were consecutively added to estimate the oxidation (activity) rates of nitrite oxidation organisms (NOB) and ammonia oxidizing organisms (AOB), respectively, as described by Moussa et al. (2003). Similarly, the denitrification process performed by heterotrophic organisms was assessed through the addition of $10 \mathrm{mg} / \mathrm{L}$ of nitrate $\left(\mathrm{NO}_{3}-\mathrm{N}\right)$ and $10 \mathrm{mg} / \mathrm{L}$ of nitrite $\left(\mathrm{NO}_{2}-\mathrm{N}\right)$ under anoxic conditions. In the denitrification tests, methanol (MeOH) was added as external carbon source to mimic, as much as possible, the operating conditions observed at the full- 
scale plant. With the objective of removing any potential residual substrate (carbon or nitrogen compounds) present in the sludge and to acclimatize the sludge samples to the temperature of study, the nitrogen sources and methanol were only added after exposing the sludge for 1 hour to the target temperature. Throughout the activity tests, samples were collected, filtered through $0.45 \mu \mathrm{m}$ pore size filters, and analyzed to determine the variations of $\mathrm{NH}_{4}-\mathrm{N}, \mathrm{NO}_{2}-\mathrm{N}, \mathrm{NO}_{3}-\mathrm{N}$ and methanol (as $\mathrm{COD}$ ) concentrations during the execution of the tests.

The experiments were conducted in a double-jacketed fermenter (1 L volume) operated under controlled temperature conditions with the help of a water-bath and a recirculator. In the nitrification tests, continuous aeration using compressed air was provided at a flowrate of 60/L to keep the dissolved oxygen (DO) concentration above $4 \mathrm{mg} / \mathrm{L}$ throughout the experiments. Meanwhile, in the denitrification tests, $30 \mathrm{~L} / \mathrm{h}$ of nitrogen gas were continuously sparged to avoid oxygen intrusion. $\mathrm{pH}$ was kept at $7.00 \pm 0.10$ with the help of a two-way $\mathrm{pH}$ controller. Process control was achieved through the operation of a control system (Applikon ADI 1030, associated with accessories, viz. DO probe, $\mathrm{pH}$ meter). All analyses, including the determination of the mixed liquor suspended solids (MLSS), mixed liquor volatile suspended solids (MLVSS) and COD were performed in accordance with standard methods (APHA, 1998).

\section{Temperature dependency}

In order to describe the temperature dependency of the BNR processess in the thermophilic range of 35 to $55^{\circ} \mathrm{C}$ (including the collapse in activity at the terminal temperature), an extended Arrhenius equation was applied (Lopez-Vazquez et al., 2007, 2009): 


$$
r_{T}=r_{35} \cdot \theta_{1}^{(T-3 S)}\left[1-\theta_{2}^{\left(T-T_{t d x}\right)}\right]
$$

Where: $r_{T}$ is the biomass activity at the temperature $T ; T$ is the temperature in ${ }^{\circ} \mathrm{C} ; \theta_{1}$ is the temperature Arrhenius coefficient $\theta$ that describes the biomass activity from $35^{\circ} \mathrm{C}$ to the optimal temperature; $T_{M A X}$ is the terminal temperature; and, $\theta_{2}$ is a second temperature coefficient that describes the declination in activity from the optimal to the terminal temperature.

\section{Modeling the 2-step nitrification-denitrification process}

The AMS3 model (Henze et al., 2000), the structure of the nitrification and denitrification model developed by Hellinga et al. (1999), and the modified ASM3 model developed by Iacopozzi et al. (2007) were adapted to describe the two step nitrification-denitrification processes. However, unlike in ASM3, no storage processes were considered in the anoxic growth kinetics since it has been shown that methanol is not taken up and stored as intracellular polymers but directly consumed instead (Purtschert and Gujer, 1999). Another difference with regard to ASM3 was the inclusion of the maximum growth rate of denitrifiers on methanol (similar to the approach followed by (Purtschert and Gujer, 1999), instead of the use of reduction factors to describe the anoxic activity (on nitrate and nitrite) as a function of the aerobic activity of heterotrophs. Ammonification and hydrolysis were not considered either because it was assumed that in the batch experiments no organic compounds were present in the liquid phase at the beginning of the tests (since the sludge samples had been exposed for 1 hour to the corresponding temperature to be applied in the test). Thus, the model only included those processes that describe the activities of autotrophic and methanoldegrading heterotrophic organisms. Once the 2-step nitrification-denitrification model was defined, the extended Arrhenius equations determined in this study were incorporated into the model to describe the BNR processess observed from 35 to $55^{\circ} \mathrm{C}$. 


\section{Microbial identification}

Fluorescence in situ Hybridization (FISH) analyses were carried out to perform an identification assessment of the nitrifying populations potentially responsible of the observed thermophilic nitrifying activity. Table 1 shows the FISH oligonucleotide probes applied in this study. All FISH analyses were executed in accordance to the hybridization conditions described in the original references (e.g. at the suggested formamide concentrations and using the required competitor probes).

\section{RESULTS}

\section{Temperature effects on nitrification and denitrification}

To assess the oxidation activities of $\mathrm{AOB}$ and $\mathrm{NOB}$, nitrification experiments were carried out on the industrial sludge following the procedure described by Moussa et al. (2003). As observed in Figures 1a and 1b, both bacterial groups showed an increase in their specific oxidation rates as the temperature increased from 35 to $50^{\circ} \mathrm{C}$, reaching an optimal rate around $50^{\circ} \mathrm{C}$ followed by a sudden drop in activity and inactivation at $55^{\circ} \mathrm{C}$. In particular, the activity of $\mathrm{AOB}$ at $35^{\circ} \mathrm{C}\left(3.3 \mathrm{mgNH}_{4}-\mathrm{N} / \mathrm{gVSS}\right.$.h) was similar to that found by Pinzon-Pardo et al. (2007) in a full-scale system operated at the same temperature. As expected (Hellinga et al. 1999), the oxidation rates of AOB were higher than those of NOB (i.e. $3.3 \mathrm{mgNH}_{4}-\mathrm{N} / \mathrm{gVSS} . \mathrm{h}$ and $2.9 \mathrm{mg} \mathrm{NO} \mathrm{NO}_{2} \mathrm{~N} / \mathrm{gVSS}$.h at $35^{\circ} \mathrm{C}$ for $\mathrm{AOB}$ and $\mathrm{NOB}$, respectively). However, at $50^{\circ} \mathrm{C}$ the $\mathrm{AOB}$ and $\mathrm{NOB}$ oxidation activities were practically identical $\left(4.6 \mathrm{mgNH}_{4}-\mathrm{N} / \mathrm{gVSS}\right.$.h versus $4.5 \mathrm{mg} \mathrm{NO} 2-\mathrm{N} / \mathrm{gVSS}$.h at $50^{\circ} \mathrm{C}$ for $\mathrm{AOB}$ and $\mathrm{NOB}$, respectively). The similar $\mathrm{AOB}$ and $\mathrm{NOB}$ nitrification kinetics led to nitrite accumulation which was somehow expected based on previous studies (inter alia Hellinga et al., 1998; Kim et al., 2008). 
Concerning the temperature dependencies, the double Arrhenius expression provided a satisfactory description of the observed activity rates of AOB and NOB from 35 to $55^{\circ} \mathrm{C}\left(\mathrm{R}^{2}\right.$ 0.99) including the bacterial inactivation at superoptimal temperatures (Figures 1a and 1b).

When compared to nitrification, the temperature dependencies of denitrification using methanol followed a slightly different trend (Figures 1c and 1d). Though the denitrification activities increased from 35 to $40^{\circ} \mathrm{C}$ (similar to the nitrification rates), neither a well-defined optimal temperature nor a sudden drop in bacterial activities at superoptimal temperatures were observed. Rather, the optimal denitrification rates on nitrite and nitrate were found around 40 and $45^{\circ} \mathrm{C}$, followed by a slow bacterial inactivation above 45 and the cease of activity at $55^{\circ} \mathrm{C}$ (terminal temperature). Due to unknown reasons, the denitrification rate over nitrate at $35^{\circ} \mathrm{C}$ was considerably higher than the rate determined by Pinzon-Pardo et al. (2007) (6.8 versus $4.6 \mathrm{mgNO}_{3}{ }^{-}-\mathrm{N} / \mathrm{gVSS} . h$ ). Nevertheless, the double Arrhenius expressions could also provide a satisfactory description of the temperature dependencies of the denitrification processes on methanol (Figures 1c and 1d). Interestingly, the denitrification rates over nitrite were consistently faster than those over nitrate ( $40 \%$ faster), indicating that the reduction of nitrate to nitrite is the limiting step in denitrification as observed in previous studies (Timmermans and Van Haute, 1983; Nowak et al., 1995).

The theoretical COD requirements for nitrate and nitrite removal using methanol are 3.5 $\mathrm{gCOD} / \mathrm{gNO}_{3}-\mathrm{N}$ and $2.2 \mathrm{gCOD} / \mathrm{gNO}_{2}-\mathrm{N}$, respectively (Mulder et al., 2001). In this regard, a stoichiometric ratio of $5.5 \mathrm{~g} \mathrm{COD}-\mathrm{MeOH} / \mathrm{gNO}_{3}-\mathrm{N}$ was observed in this study that is higher (but comparable) to those reported by Nyberg et al. (1992), Purtschert et al. (1996), Purtschert and Gujer, 1999; Henze et al. (2000) and Pinzon-Pardo et al. (2007) of around 4.8-5.2 gCOD$\mathrm{MeOH} / \mathrm{gNO}_{3}-\mathrm{N}$ in full-scale applications. Similarly, a ratio of $2.6 \mathrm{gCOD}-\mathrm{MeOH} / \mathrm{gNO}_{2}-\mathrm{N}$ was 
measured for the denitrification process over nitrite that is slightly higher than that observed by Mulder et al. (2001). In spite of the higher stoichiometric ratios, they were constant and independent on temperature.

\section{Modeling}

The model (presented in Tables S1-S2 in the supplementary material) provided a satisfactory description of the 2-step nitrification (Figure 2), including the nitrite accumulation at the different temperatures of study due to the higher AOB activities. Similarly, the 2-step denitrification activities observed from 35 to $55^{\circ} \mathrm{C}$ were also well-described (Figure 3), though no nitrite accumulation was noticed due to the higher removal rates of nitrite compared to those of nitrate. The satisfactory description of the 2-step nitrificationdenitrification activities was attained through the adjustment of (i) the biomass growth yields on methanol with either nitrate or nitrite as electron acceptors (to 0.48 and $0.33 \mathrm{gCOD} / \mathrm{gCOD}$, respectively), (ii) the inclusion of the temperature dependencies of nitrification and denitrification from 35 to $55^{\circ} \mathrm{C}$, and (iii) the adjustment of the anoxic decay rate of heterotrophs $\left(b_{\mathrm{H}, \mathrm{N}}\right)$ to $0.25 \mathrm{~d}^{-1}$. For other parameters, ASM3 default values were used (Henze et al. 2000) with the exception of the biomass growth rates of AOB and NOB that were adjusted to 0.15 and $0.04 \mathrm{~d}^{-1}$, respectively (as applied by Hellinga et al., 1999).

\section{Microbial identification}

The microbial identification via FISH indicated that AOB bacteria from the Nitrosomonads (halotolerant and obligatelohalophilic) and Nitrosomonas oligotropha lineages were present in the sludge (Figures $4 \mathrm{a}$ and $4 \mathrm{~b}$ ). Based on the oligonucleotide probes applied in this study (Table 1), other AOB or NOB were not detected. 


\section{DISCUSSION}

\section{Higher temperature effects on nitrification and denitrification}

Whereas nitrification has been often observed in soils, solid waste treatment and composting applications (Stark 1996; Choi and Eum, 2002; Berge et al., 2007; Maeda et al. 2010), only a few studies have documented the occurrence of nitrification above $40^{\circ} \mathrm{C}$ in activated sludge systems (Barrit, 1933; Hellinga et al., 1998). Usually, nitrification fails at temperatures higher than $40^{\circ} \mathrm{C}$ (Sudarno et al., 2011). Nevertheless, in those studies where nitrification was observed above $40^{\circ} \mathrm{C}$, the optimal temperature was found around $37-40^{\circ} \mathrm{C}$ (Stark, 1996; Hellinga et al., 1998). Conversely, in this study $50^{\circ} \mathrm{C}$ was the optimal temperature for nitrification. Despite that the higher wastewater operating temperature at the refinery $\left(34^{\circ} \mathrm{C}\right)$ could be assumed to be the main factor that leads to the selection of thermophilic organisms, certainly there appear to be other operating and environmental factors. In an attempt to explore the key factors that lead to the selection of thermophilic nitrifying and denitrifying bacteria in industrial wastewater treatment plants, Chikamba (2009) executed a similar set of experiments on different plants (involving another oil-refinery, a food and beverage industry, a fermentation industry and another tannery) operated at between 30 and $35^{\circ} \mathrm{C}$, and one municipal plant operated at $15-20^{\circ} \mathrm{C}$. However, all failed to show bacterial activity above $40^{\circ} \mathrm{C}$. The use of pure oxygen in the plant described in this study appears to be the main difference compared to the plants studied by Chikamba (2009). In a study performed for 2

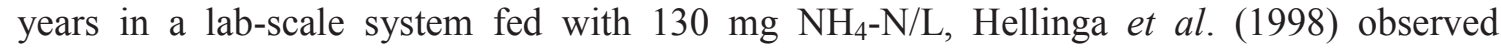
ammonium oxidation activity up to $55^{\circ} \mathrm{C}$ with an optimal temperature around $40^{\circ} \mathrm{C}$. They reported that the selection pressure created by the applied operating conditions (such as high N-concentrations, high temperature and short SRT) led to the selection of organisms with a lower affinity for substrates (e.g. higher half-saturation constants for substrates such as ammonia and oxygen). Thus, higher nitrogen concentrations can be hypothesized to be 
another relevant factor (in addition to the higher temperature), implying that higher influent nitrogen concentrations (potentially combined with the return of high-strength N-containing flows from the sludge handling facilities) contribute to the selection of thermophilic nitrifying bacteria. In this regard, the oil-refinery wastewater treatment plant where the sludge was collected contained around $205 \mathrm{mg} / \mathrm{L}$ of Total Kjeldhal Nitrogen (TKN) and $93 \mathrm{mgNH}_{4}-\mathrm{N} / \mathrm{L}$ (Pinzon-Pardo et al., 2007), which could have favored the growth of thermophilic organisms. Nevertheless, it cannot be discarded that the use or a combined effect of different factors such as higher temperature, higher nitrogen concentrations, use of pure oxygen rather than air (which can increase the oxygen transfer efficiency), salinity levels, reactor configurations, internal recycle of high strength nitrogen flows can potentially lead to the selection of thermophilic nitrifying organisms in full-scale activated sludge systems.

Interestingly, the denitrification rates over nitrite were consistently higher than those over nitrate indicating that the reduction of nitrate to nitrite is the limiting step in denitrification as also observed in previous studies (Timmermans and Van Haute, 1983; Nowak et al., 1995). Two potential explanations could be (i) the potential inhibition of nitrate reduction due to the presence of nitrite (Timmermans and Van Haute, 1983) or (ii) that nitrite is more reduced than nitrate requiring lesser $\mathrm{COD}\left(3.5 \mathrm{gCOD} / \mathrm{gNO}_{3}-\mathrm{N}\right.$ and $2.2 \mathrm{gCOD} / \mathrm{gNO}_{2}-\mathrm{N}$ ) (Mulder et al., 2001).

As expected, above $30^{\circ} \mathrm{C}$ the activity of $\mathrm{AOB}$ was higher than that of $\mathrm{NOB}$, favoring the accumulation of nitrite. Also, the denitrification activity over nitrite proceeded twice as fast as the denitrification over nitrate (also requiring about 40\% less COD). These conditions suggest that it can be potentially feasible to achieve BNR via nitritation and denitritation, contributing to reduce the operational costs of the plants in terms of aeration and external carbon source 
dosage. Furthermore, it must be noticed that, if the influent wastewater does not contain toxic or inhibitory compounds to Anammox bacteria, the environmental and operating conditions of this plant (e.g. higher temperature, high $\mathrm{N}$ concentrations and, therefore, high potential for partial nitrification) make it a suitable candidate for the implementation of the Anammox process in the main-stream treatment line (Kartal et al., 2010). The latter may further reduce the environmental impact and operational costs (due to the lower gas emissions and because methanol would not be longer required for denitrification). Further research is needed to elucidate the factors that influence the occurrence of thermophilic nitrifying organisms and event to explore the potential implementation of the Anammox process in the main-stream ine of such industrial wastewater treatment plants. This can potentially lead to the re-design of current industrial activated sludge systems that deal with high $\mathrm{N}$-concentration wastewater streams.

\section{Temperature dependencies}

The Arrhenius temperature coefficients of the nitrifying organisms observed in this study (Table 2) were considerably lower than those reported previously (e.g. 1.02 and 1.03 versus 1.12), indicating a low sensitivity or temperature dependence from 35 to $55^{\circ} \mathrm{C}$. Similarly, the temperature coefficients for denitrification were in the low range of those reported elsewhere for similar cultures (Table 2). Accordingly, previous studies had already suggested the need to develop and apply different models to describe the activity of organisms at temperatures higher than $25^{\circ} \mathrm{C}$ (Wett et al., 2011). The mains reason being that ASM1 and ASM3 are only limited to a temperature range between 10 and $25^{\circ} \mathrm{C}$ (Henze et al., 2000), and that the use of the temperature coefficients proposed in those models overestimate the activity of nitrifying bacteria above $25^{\circ} \mathrm{C}$ (Wett et al., 2011). Thus, the double Arrhenius expressions developed in this study proved capable to describe the nitrification and denitrification activities from 35 to 
$50^{\circ} \mathrm{C}$ including their inactivation (Figure 1). Though attempts were made to expand the applicability to a broader temperature range, the expressions developed in this study were not suitable to describe the activities out of the temperature range studied in this research (e.g. below $35^{\circ} \mathrm{C}$ or above $50^{\circ} \mathrm{C}$ ) (data not shown). Trying to find a unified expression, another attempt was made to use the quadratic temperature dependency equation developed by Wett et al. (2011) for nitrifying organisms for a temperature interval between 10 and $50^{\circ} \mathrm{C}$. However, a satisfactory description was not obtained. Possibly, the nitrifying activities observed in the different studies are a reflection of the occurrence of different nitrifying communities that have different temperature dependencies. This implies that the expressions are case-sensitive and likely dependent on local conditions and on the occurrence of the nitrifying organisms.

\section{Modelling}

After the adjustment of the biomass growth yields of denitrifying organisms, the incorporation of the double Arrhenius temperature expressions and fixing the anoxic decay rate of heterotrophs, the modified ASM3 model developed in this study proved capable to correctly predict the activity of the nitrifying and denitrifying organisms from 35 to $55^{\circ} \mathrm{C}$ (Figures 2 and 3). The anoxic growth (denitrification) on storage polymers (as described in ASM3) was not included since it has been shown that methanol is not converted into storage polymers but consumed directly (Purtschert and Gujer, 1999). This occurs likely due to the involvement of a specific group of methanol-degrading organisms (Hyphomicrobium sp.), rather than to the presence of ordinary heterotrophs, as postulated by Timmermans and van Haute (1983). The satisfactory description of the biomass activities supports this approach (Figure 3).

The anoxic decay rate of ordinary heterotrophs $\left(\mathrm{b}_{\mathrm{HN}}\right)$ was fixed to $0.25 \mathrm{~d}^{-1}$ instead of keeping the values given by the Arrhenius temperature expressions of ASM3 because they tended to 
considerably overestimate the denitrification processes over nitrite and nitrate as temperature increased (data not shown). As observed in Figure 3e for the denitrification batch experiments executed at $55^{\circ} \mathrm{C}$, the model correctly predicts no consumption of methanol. However, since the anoxic decay process takes place continuously the model still predicts the consumption of nitrite and nitrate, which was more pronounced before fixing the anoxic decay rate at $0.25 \mathrm{~d}^{-1}$. Salem et al. (2006) also inferred that the temperature coefficients for autotrophic decay in ASM overestimate the decay at higher temperature. Due to the lack of information concerning the temperature effects on the anoxic decay rate, the constant value of $0.25 \mathrm{~d}^{-1}$ provided a satisfactory description. Nevertheless, further research is needed to determine the temperature dependency of this process.

In this manuscript, an extended ASM3 model describing nitrification as a two-step process and the simultaneous denitrification on nitrite and nitrate was presented. This enabled the model to correctly describe nitrite accumulation during nitrification and the facultative denitrification on nitrite and nitrate using methanol as external carbon source. The incorporation of double Arrhenius expressions to describe nitrification and denitrification enabled to extend the application of the model to a temperature beyond that considered in ASM1 and ASM3. As such, this model has the potential to be used as a reliable tool to assess and possibly improve and optimize the operation of wastewater treatment plants performing biological nitrogen removal at temperatures higher than $35^{\circ} \mathrm{C}$.

\section{Microbial communities}

Interestingly, only two groups of AOB (Nitrosomonads and Nitrosomonas oligotropha) were identified using FISH (Figures $4 \mathrm{a}$ and $4 \mathrm{~b}$ ). However, no NOB were detected. In other wastewater treatment applications, AOB such as Nitrosomonas oligotropha have also been 
observed as well as Nitrosomonas nitrosa-like and Nitrosomonas nitrosa at temperatures higher than $30^{\circ} \mathrm{C}$ but lower than $45^{\circ} \mathrm{C}$ (Avrahami et al. 2011; Shore et al., 2012). Nevertheless, other types of AOB (Nitrosomonas europaea/eutropha clusters) have also been identified at higher temperature in manure composting applications at $70^{\circ} \mathrm{C}$ at high $\mathrm{N}$ concentrations (of around 2000mg $\mathrm{NH}_{4}-\mathrm{N} / \mathrm{gTSS}$ ) (Yamamoto et al., 2010). As discussed previously, the latter is in accordance to previous observations regarding the favourable effect of high N-concentrations on the occurrence of thermophilic nitrifying organisms.

Concerning NOB, Nitrospira spp. has been observed in other studies between 30 and $45^{\circ} \mathrm{C}$ (Shore et al. 2012), but they were not detected in this study either. As such, a broader molecular study is needed to identify the nitrifying organisms responsible for thermophilic nitrification in this and other industrial wastewater treatment plants operated under similar conditions (e.g. high temperature with high $\mathrm{N}$-concentrations, using pure oxygen as electron acceptor and methanol as electron donor).

Recent studies (Gilch, 2009) performed on Nitrosomonas europaea revealed that on the gene level the optimum temperature for the reaction of hydroxylamin conversion by ammonia monooxygenase lies around 45 to $50^{\circ} \mathrm{C}$. This suggests that the environmental and operating conditions applied in engineered systems (such as sewage treatment plants) are usually not optimal and therefore might limit the biological ammonium and nitrite oxidation processes. Aspects such as the ammonia and nitrite concentrations (and even the reactor configurations the recirculation of internal and reject flows) and the dissolved oxygen concentration need to be correctly taken into account since they may play an important role affecting the occurrence of the microbial communities involved in BNR at full-scale (industrial) activated sludge wastewater treatment plants. 
These findings can be of major importance to contribute to reduce the operational costs of wastewater treatment plants that treat warm industrial wastewaters. Assuming that in the oilrefinery industry the initial wastewater temperature is around $65^{\circ} \mathrm{C}$ (personal communication with plant practitioners), the thermophilic BNR would allow to reducing the temperature in only $15^{\circ} \mathrm{C}$ (to $50^{\circ} \mathrm{C}$ ) instead of having to reduce it in about $30^{\circ} \mathrm{C}$ (to around $35^{\circ} \mathrm{C}$ ). This implies a reduction of up to $50 \%$ in the cooling capacity that can help to significantly reduce the operational costs and environmental impact of several industries (not only from the oilrefinery industry but also from the food industry, tanneries, among others).

\section{ACKNOWLEDGEMENTS}

The authors sincerely acknowledge the cooperation from various WWTP managers and practitioners during the collection of activated sludge samples to perform the laboratory activity tests. M. Kubare and C. Chikamba want to thank the Netherlands organization for international cooperation in higher education (Nuffic) for the financial support to undertake their MSc studies at UNESCO-IHE Institute for Water Education.

\section{REFERENCES}

Amman RI, Binder BJ, Olson RJ, Chisholm SW, Devereux R, Stahl DA (1990) Combination of 16S rRNAtargeted oligonucleotide probes with flow cytometry for analyzing mixed microbial populations. App Environ Microbiol 56, 1919-1925.

APHA (1998) Standard methods for the examination of water and wastewater, American Public Health Association/American Water Works Association, Washington DC, US.

Avrahami S, Jia Z, Neufeld JD, Murrel JC, Conrad R, Küsel K (2011) Active autotrophic ammnonia-oxidizing bacteria in biofilm enrichments from simulated creek ecosystems at two ammonium concentrations respond to temperature manipulation. App Environ Microbiol, 77(20): 7329-7338.

Barrit NW (1933) The nitrification process in soils and biological filters. Annals App Biology, DOI: 10.1111/j.1744-7348.1933.tb07433.

Berge ND, Reinhart DR, Dietz JD, Townsend T. (2007) The impact of temperature and gas-phase oxygen on kinetics of in situ ammonia removal in bioreactor landfill leachate. Wat Res, 41:1907-1914.

Buswell AM, Shiota T, Lawrence N, van Meter J (1954) Laboratory studies on the kinetics of the growth of Nitrosomonas with relation to the nitrification phase of the B.O.D. test. J Gral Microbiol 54,1-14.

Carrera J, Vicent T, Lafuente FJ (2003) Influence of temperature on denitrification of an industrial high-strength nitrogen wastewater in a two-sludge system. Water SA, 29(1):11-16. 
Chikamba (2009) Nitrogen removal at high temperatures: Industrial applications, MSc thesis, UNESCO-IHE, Delft, The Netherlands

Choi E, Eum Y. (2002) Strategy for nitrogen removal from piggery waste. Wat Sci Tech, 46(6-7):347-354.

Christensson M, Lie E, Welander T (1994) A comparison between ethanol and methanol as carbon sources for denitrification. Water Sci Tech, 30(6):83-90.

Daims H, Bruh A, Amann R, Schleifer KH, Wagner M (1999) The domain-specific probe EUB338 is insufficient for the detection of all bacteria: development and evaluation of a more comprehensive probe set. Syst App Microbiol 22, 434-444.

Daims H, Nielsen P, Nielsen JL, Juretschko S, Wagner M (2000) Novel Nitrospira-like bacteria as dominant nitrite oxidizers in biofilms from wastewater treatment plants: diversity and in situ physiology. Water Sci Tech 41, 85-90.

Gieseke A, Purkhold U, Wagner M, Amann R, Schramm A (2001) Community structure and activity dynamics of nitrifying bacteria in a phosphate-removing biofilm. Appl Environ Microbiol 67, 1351-1362.

Gilch S (2009) Molecular and physiological characterization of the energy of Nitrosomonas europaea (in German). $\mathrm{PhD}$ dissertation. University of Bayreuth. Germany. http://opus.ub.unibayreuth.de/volltexte/2010/668/

Guo JH, Peng YZ, Huang HJ, Wang SY, Ge SJ, Zhang JR, Wang ZW (2010) Short- and long-term effects of temperature on partial nitrification in a sequencing batch reactor treating domestic wastewater. J. Hazard Mater 179:471-479.

Hellinga C, Schellen AA JC, Mulder JW, Loosdrecht MCM, Heijnen JJ (1998) The SHARON process: An innovative method for nitrogen removal from ammonium-rich waste water. Water Sci Tech, 37:135142.

Hellinga C, van Loosdrecht M.C.M., Heijnen JJ (1999) Model-based design of a novel process for nitrogen removal from concentrated flows. Math Comput Model Dynamic Sys, 5(4):351-371.

Henze M, Gujer W, Mino T, van Loosdrecht MCM. 2000. Activated sludge models ASM1, ASM2, ASM2d and ASM3. IWA Scientific and Technical Report No. 9. IWA Task Group on Mathematical Modelling for Design and Operation of Biological Wastewater Treatment. London: IWA Publishing.

Henze M, Harremoes P, Jansen JLC, Arvin E (1995) Wastewater Treatment: biological and chemical processes, Springer-Verlag, Berlin, Germany.

Henze M, van Loosdrecht MCM, Ekama GA, Brdjanovic D (2008) Biological Wastewater Treatment: Principles, Modeling and Design. IWA publishing. London, UK.

Hiorns WD, Hastings RC, Head IM, McCarthy AJ, Saunders JR, Pickup RW, Hall GH (1996) Amplification of 16S ribosomal RNA genes of autotrophic ammonia-oxidizing bacteria demonstrates the ubiquity of nitrosospiras in the environment. Microbiol 141, 2793-2800.

Iacopozzi I, Innocenti V, Marsili-Libelli S, Giusti E (2007) A modified activated sludge model no. 3 (ASM3) with two-step nitrification-denitrification. Environ Modelling Software, 22:847-861.

Juretschko S, Timmermann G, Schmid M, Schleifer KH, Pommerening-Roser A, Koops HP, Wagner M (1998) Conbined molecular and conventional analyses of nitrifying bacterium in activated sludge: Nitrosococcus mobilis and Nitrospira-like bacteria as dominant populations. Appl Environ Microbiol 64:3042-3051.

Kartal B, Kuenen JG, van Loosdrecht M.C.M. (2010). Sewage treatment with Anammox. Science 38, $702-703$.

Kim J-H, Guo X, Park H-S (2008) Comparison study of the effects of temperature and free ammonia concentration on nitrification and nitrite accumulation. Process Biochem, 43:154-160.

Laudelout H, van Tichelen L (1960) Kinetics of the nitrite oxidation by Nitrobacter Winogradskyi. J Bacteriology 79:39.

Lopez-Vazquez CM, Song YI, Hooijmans CM, Brdjanovic D, Moussa MS, Gijzen HJ, van Loosdrecht MCM. 2007. Short-term temperature effects on the anaerobic metabolism of glycogen accumulating organisms. Biotech Bioeng, 97(3):483-495.

Lopez-Vazquez CM, Hooijmans CM, Brdjanovic D, Gijzen HJ, van Loosdrecht MCM (2009) Temperature effects on glycogen accumulating organisms. Water Res, 43(11):2852-2864 .

Maeda K, Morioka R, Hanajima D, Osada T (2010) The impact of using mature compost on nitrous oxide emission and the denitrifier community in the cattle manure composting process. Microb Ecol, 59:2536.

Mobarry BK, Wagner M, Urbain V, Rittmann BE, Stahl DA (1996) Phylogenetic probes for analyzing abundance and spatial organization of nitrifying bacteria. Appl Environ Microbiol, 62:2156-2162.

Moussa MS, Lubberding HJ, Hooijmans CM, Van Loosdrecht MCM, Gijzen HJ (2003) Improved method for determination of ammonia and nitrite oxidation activities in mixed cultures. App Microbiol Biotech, 63:217-221.

Moussa MS, Rojas AR, Hooijmans CM, Gijzen HJ, van Loosdrecht MCM (2004) Model-based evaluation of nitrogen removal in a tannery wastewater treatment plant. Wat Sci Tech, 50:251-260. 
Mulder JW, van Loosdrecht MCM, Hellinga C, van Kempen R (2001) Full-scale application of the SHARON process for treatment of rejection water of digested sludge dewatering. Wat Sci Tech, 43(11):127-134.

Nowak O, Svardal K, and Schweighofer P (1995) The dynamic behaviour of nitrifying sludge systems influenced by inhibiting wastewater compounds. Wat Sci Tech, 31(2):115-124.

Nyberg U, Aspegren H, Andersson B, Janssen JC, Villadsen IS (1992) Full-scale application of nitrogen removal with methanol as carbon source. Wat Sci Tech, 26(5-6):1077-1086.

Oleszkiewicz JA, Berquist SA (1988) Low temperature nitrogen removal in sequencing discontinuos reactors. Water Res, 22 (9):1163-1171.

Pinzon-Pardo AL, Brdjanovic D, Moussa MS, Lopez-Vazquez CM, Meijer SCF, Van Straten HHA, Janssen AJH, Amy G, van Loosdrecht MCM (2007) Application of ASM3 to an oil refinery wastewater treatment plant. Environ Technol, 28:1273-1284.

Purtschert I, Gujer W (1999) Population dynamics by methanol addition in denitrifying wastewater treatment plants. Wat Sci Tech, 39(1):43-50.

Purtschert I, Siegrist H, Gujer W. (1996) Enhanced denitrification with methanol at WWTP Zürich-Werdhölzli. Wat Sci Tech, 33(12):117-126.

Salem S, Berends DHJG, van Loosdrecht MCM, Heijnen J (2002) Model-based evaluation of a new upgrading concept for nitrogen removal. Water Sci Tech, 45(6):169-176.

Shore JL, McCoy WS, Gunsch CK, Deshusses MA (2012) Application of a moving bed biofilm reactor for tertiary ammonia treatment in high temperature industrial wastewater. Biores Technol, 112:51-60.

Stark JM (1996) Modeling the temperature response of nitrification. Biogeochemistry 35: 433-445.

Sudarno U, Winter J, Gallert C (2011) Effect of varying salinity, temperature, ammonia and nitrous acid concentrations on nitrification of saline wastewater in fixed-bed reactors. Biores Technol, 102 (10): 5665-5673.

Timmermans P, van Haute A (1983) Denitrification with methanol. Fundamental work of the growth and denitrification capacity of Hyphomicrobium sp. Water Res, 17(10):1249-1255.

Wagner M, Rath G, Amann R, Koops HP, Schleifer KH (1995) In-situ identification of ammonia-oxidizing bacteria. System Appl Microbiol, 18:251-264.

Wagner M, Rath G, Koops HP, Flood J, Amann R (1996) In-situ analysis of nitrifying bacteria in sewage treatment plants. Water Sci Tech, 34:237-244.

Wett B, Jimenez JA, Takacs I, Murthy S, Bratby JR, Holm NC, Ronner-Holm SGE (2011) Models for nitrification process design: one or two AOB populations? Wat Sci Tech, 66:568-578,

Willers HC, ten Have PJW, Derikx PJL, Arts MW (1993) Temperature-depencency of nitrification and required anoxic volume for denitrification in the biological treatment of veal calf manure. J Bioscience Technol $43,47-52$.

Yamamoto N, Otawa K, Nakai Y (2010) Diversity and abundance of ammonia-oxidizing bacteria and ammoniaoxidizing Archaea during cattle manure composting. Environ Microbiol, 60:807-815. 


\section{LIST OF FIGURES}

Figure 1 - Temperature effects from 35 to $55^{\circ} \mathrm{C}$ on the activity of (a) ammonia-oxidizing bacteria ( $A O B),(b)$ nitrite-oxidizing bacyeria (NOB), (c) denitrification over nitrate and (d) denitrification over nitrite.

Figure 2 - Model simulations of the nitrifying activities of ammonia-oxidizing organisms and nitrite oxidizing organisms at (a) $35^{\circ} \mathrm{C}$, (b) $40^{\circ} \mathrm{C}$, (c) $45^{\circ} \mathrm{C}$, (d) $50^{\circ} \mathrm{C}$ and (e) $55^{\circ} \mathrm{C}$. Black squares represent the $\mathrm{NH}_{4}{ }^{+}-\mathrm{N}$ concentrations; green squares: $\mathrm{NO}_{3}{ }^{-} \mathrm{N}$ concentrations; and, blue diamonds: $\mathrm{NO}_{2}{ }^{-}-\mathrm{N}$ concentrations. Green squares may appear light gray in black and white printouts.

Figure 3 - Model simulations of the denitrifying activities over nitrate and nitrite with methanol $(\mathrm{MeOH})$ as external carbon source observed in the batch activity tests executed at (a) $35^{\circ} \mathrm{C}$, (b) $40^{\circ} \mathrm{C}$, (c) $45^{\circ} \mathrm{C}$, (d) $50^{\circ} \mathrm{C}$ and (e) $55^{\circ} \mathrm{C}$. Violet circles represent the $\mathrm{MeOH}$ concentrations; black squares: $\mathrm{NO}_{3}{ }^{-}$ $-\mathrm{N}$ concentrations; and, blue diamonds: $\mathrm{NO}_{2}^{-}-\mathrm{N}$ concentrations. Violet circles may appear light gray in black and white printouts.

Figure 4 - Bacterial population distribution observed in the mixed liquor sample from the oil-refinery by applying Fluorescence in situ Hybridization (FISH) (bar indicates $20 \mu \mathrm{m}$ ): (a) Ammonia oxidizer halotolerant and obligatehalopjhilic (NEU653): green, and EUBacteria: blue; (b) Nitrosomonas Oligotropha lineage (NOLI 191): green, and EUBacteria: blue. 
Table 1. Fluorescence in situ Hybridization (FISH) oligonucleotide probes used in this study for the microbial identification of ammonia- and nitrite-oxidizing organisms.

\begin{tabular}{|c|c|c|c|}
\hline Probe & & Target organism & Reference \\
\hline EUB mix & All bacteria & $\begin{array}{l}\text { Eubacteria, Planctomyces branch (suplemment for } \\
\text { EUB338), Verrucomicrobia (suplemment for EUB338) }\end{array}$ & $\begin{array}{l}\text { Amman et al. (1990), } \\
\text { Daims et al. (1999) }\end{array}$ \\
\hline $\mathrm{Nm} 75$ & \multirow{8}{*}{$\begin{array}{l}\text { Ammonia } \\
\text { oxidizers }\end{array}$} & Nitrosomonas genus & Hiorns et al. (1996) \\
\hline Nse1472 & & $\begin{array}{l}\text { Nitrosomonas europaea, Nitrosomonas eutropha, } \\
\text { Nitrosomonas halophila }\end{array}$ & Juretschko et al. (1998) \\
\hline NOLI 191 & & Nitrosomonas oligotropha lineage & Gieseke et al. (2001) \\
\hline Nso 1225 & & Ammonia oxidizing Beta- proteobacteria & Mobarry et al. (1996) \\
\hline Nso 190 & & Ammonia oxidizing Beta- proteobacteria & Mobarry et al. (1996) \\
\hline Neu 653 & & $\begin{array}{l}\text { Nitrosomonads (halotolerant and obligatehalophilic) } \\
\text { (applied with NEU653comp) }\end{array}$ & Wagner et al. (1995) \\
\hline $\mathrm{NmV}$ & & Nitrosoccus mobilis & Juretschko et al. (1998) \\
\hline Nsv 443 & & Nitrosospira, Nitrosolobus, Nitrosovibrio & Mobarry et al. (1996) \\
\hline Ntspa 712 & \multirow{4}{*}{$\begin{array}{l}\text { Nitrite } \\
\text { oxidizers }\end{array}$} & $\begin{array}{l}\text { Phylum Nitrospira (Nitrospira-like organisms) } \\
\text { (applied with comp Ntspa 712) }\end{array}$ & Daims et al. (2000) \\
\hline NIT 1035 & & Nitrobacter (applied with NIT1035comp) & Wagner et al. (1996) \\
\hline Ntspa 662 & & $\begin{array}{l}\text { Phylum Nitrospira (Nitrospira-like organisms) } \\
\text { (applied with comp Ntspa 662) }\end{array}$ & Daims et al. (2000) \\
\hline Ntspa 712 & & Phylum Nitrospira (applied with comp Ntspa 712) & Daims et al. (2000) \\
\hline
\end{tabular}


Table 2 - A comparison of different Arrhenius temperature coefficients for nitrification and denitrification observed in literature and found and applied in this study.

\begin{tabular}{|c|c|c|c|c|}
\hline Culture & $\begin{array}{c}\text { Temperature } \\
\text { range }\left({ }^{\circ} \mathrm{C}\right)\end{array}$ & $\begin{array}{c}\text { Temperature } \\
\text { coefficient }\end{array}$ & $\begin{array}{l}\text { Carbon } \\
\text { source }\end{array}$ & Reference \\
\hline \multicolumn{5}{|c|}{ Nitrification } \\
\hline Mixed & $10-25$ & 1.12 & N/A & Henze et al. (1995) \\
\hline Mixed & $10-25$ & 1.05 & N/A & Smith et al. (2004) \\
\hline Mixed & $35-50$ & 1.03 & N/A & This study \\
\hline Mixed & $35-50$ & 1.02 & N/A & This study \\
\hline \multicolumn{5}{|c|}{ Denitrification } \\
\hline Pure & $6-30$ & 1.13 & Methanol & $\begin{array}{c}\text { (Timmermans and van } \\
\text { Haute, 1983) }\end{array}$ \\
\hline \multirow{2}{*}{ Mixed } & $7-15$ & 1.06 & Influent & \multirow{2}{*}{$\begin{array}{c}\text { (Oleszkiewicz and } \\
\text { Berquist, 1998) }\end{array}$} \\
\hline & $2-7$ & 1.30 & wastewater & \\
\hline \multirow[t]{2}{*}{ Pure } & \multirow{2}{*}{$15-25$} & 1.11 & Methanol & \multirow{2}{*}{$\begin{array}{l}\text { (Christensson and } \\
\text { Welander, 1994) }\end{array}$} \\
\hline & & 1.12 & Ethanol & \\
\hline Mixed & $10-25$ & 1.07 & - & Henze et al. (1995) \\
\hline \multirow{2}{*}{ Mixed } & \multirow{2}{*}{$7-17$} & 1.06 & Methanol & \multirow{2}{*}{ Nyberg et al. (1992) } \\
\hline & & 1.06 & Ethanol & \\
\hline Mixed & $6-10$ & 1.37 & Methanol & $\begin{array}{l}\text { (Barlindhaug and } \\
\text { Odegaard, 1996) }\end{array}$ \\
\hline Mixed & $10-25$ & 1.10 & Methanol & (Carrera et al., 2003) \\
\hline Mixed & $35-55$ & 1.04 & Methanol & This study ${ }^{1}$ \\
\hline Mixed & $35-55$ & 1.07 & Methanol & This study ${ }^{2}$ \\
\hline
\end{tabular}

1. Denitrification over nitrite

2. Denitrification over nitrate. 

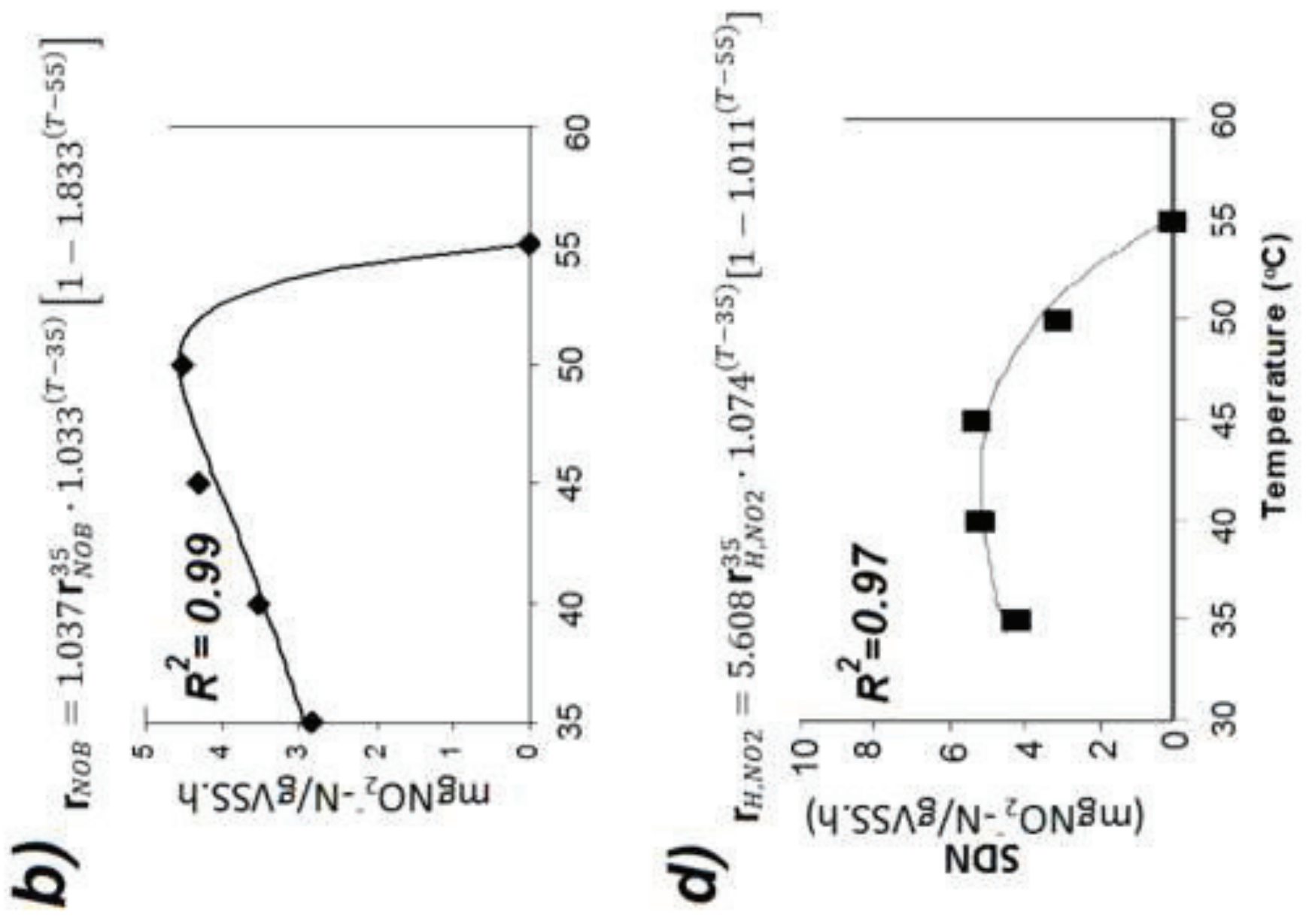

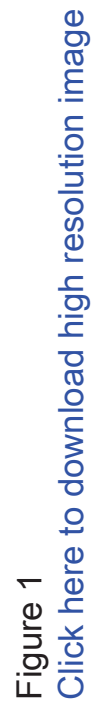
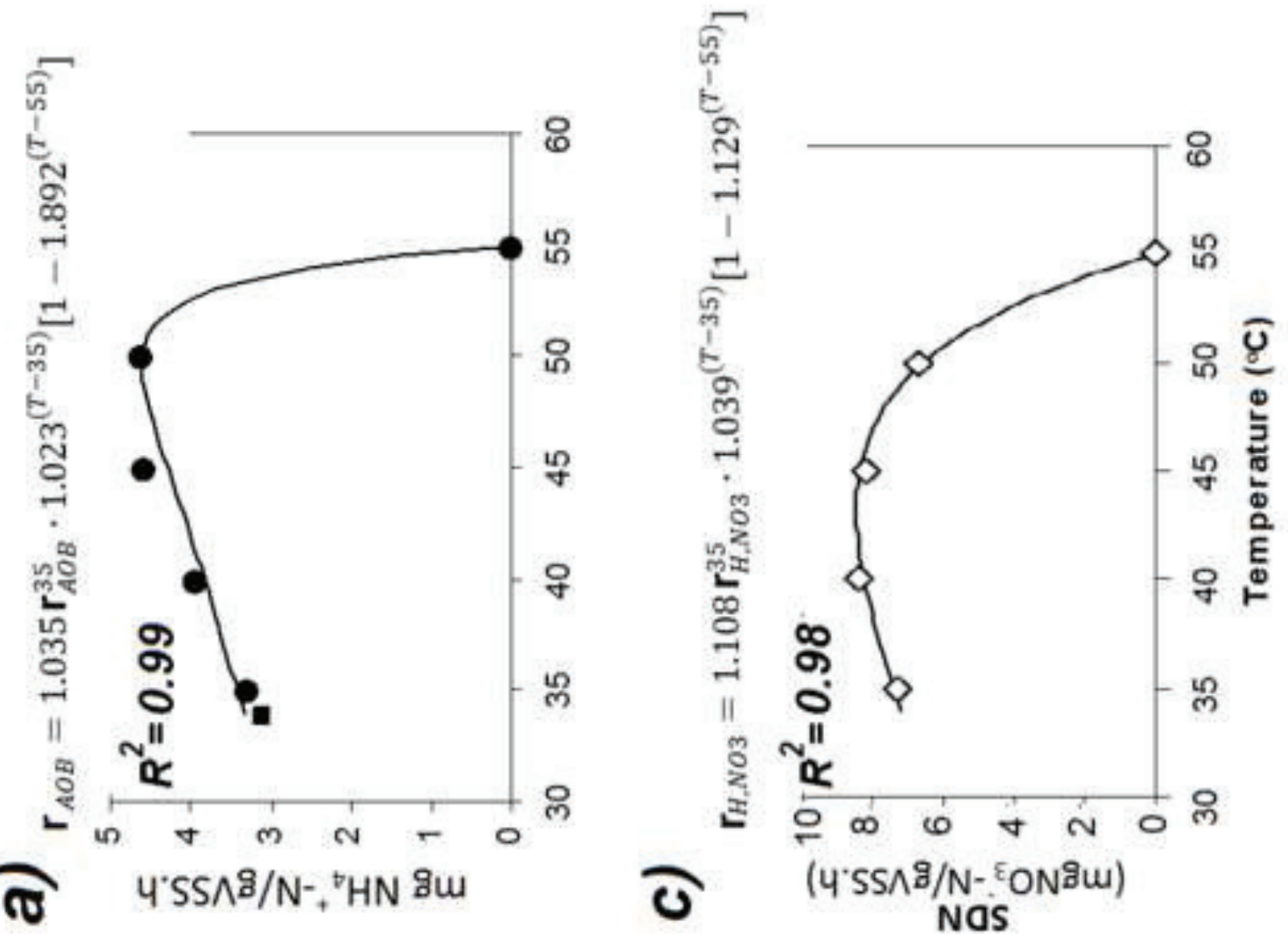

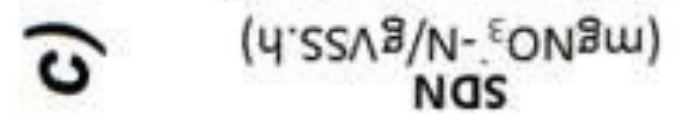



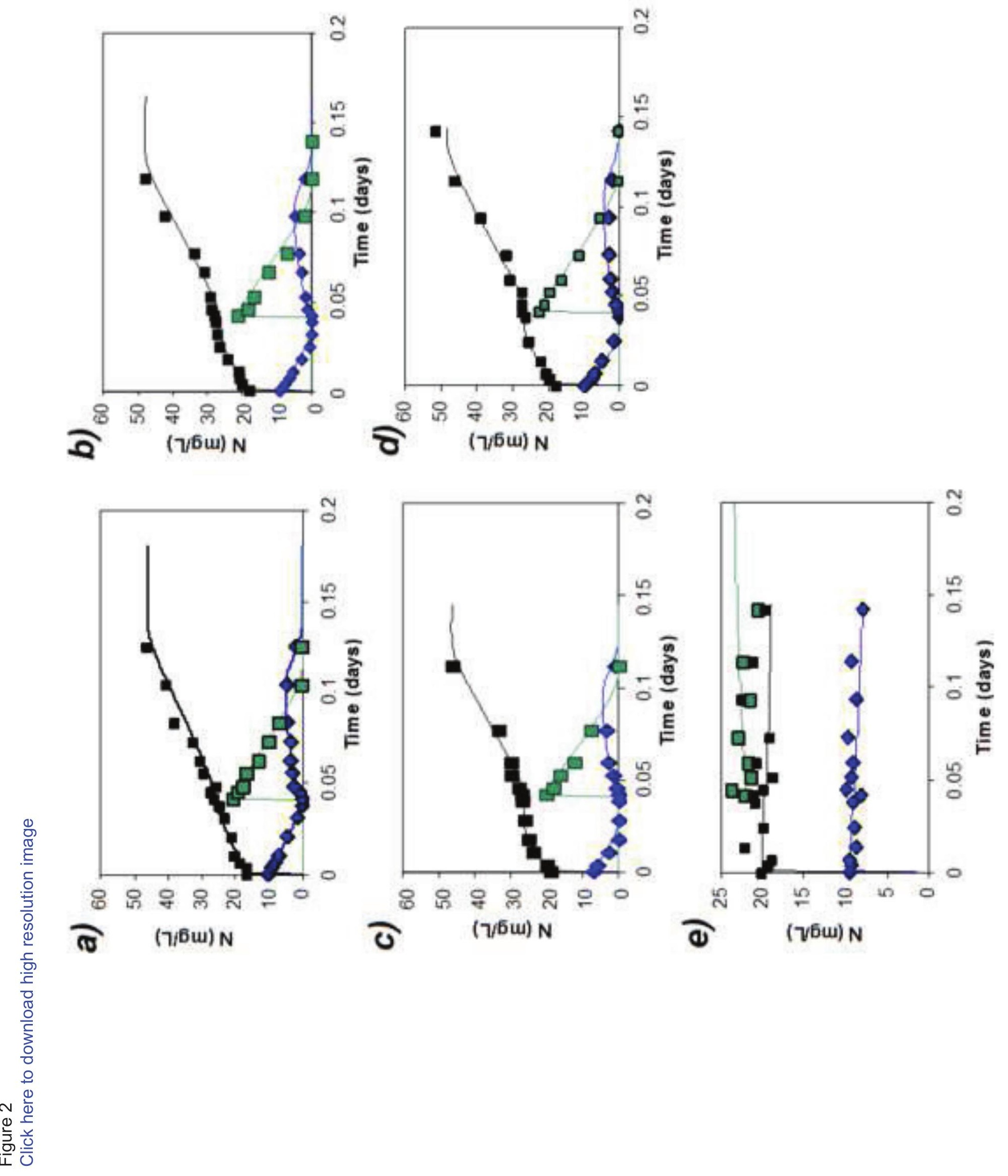
a)

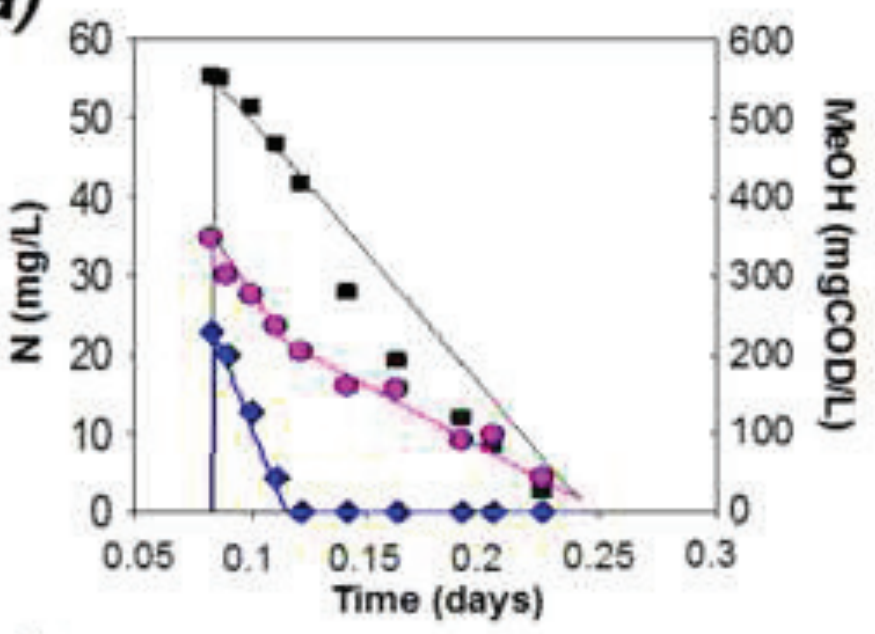

c)

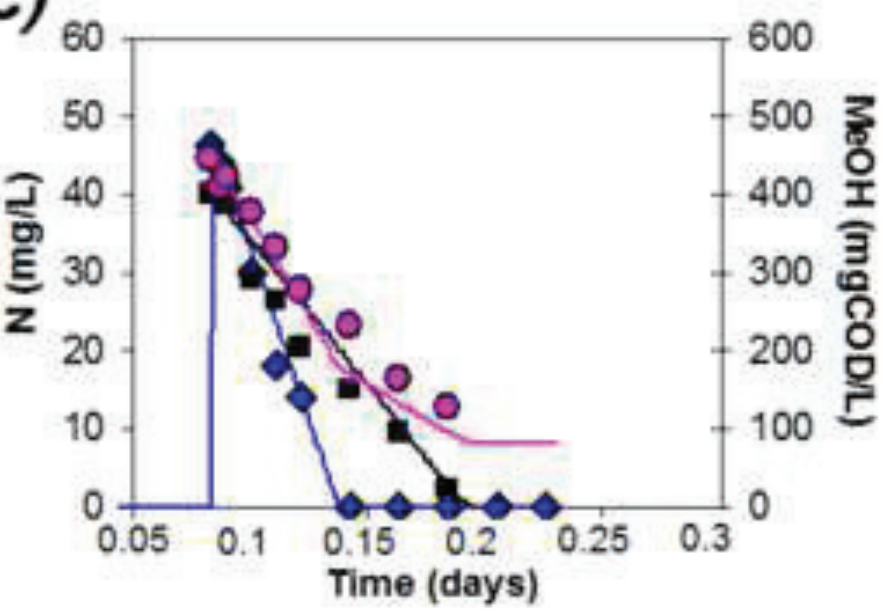

e)

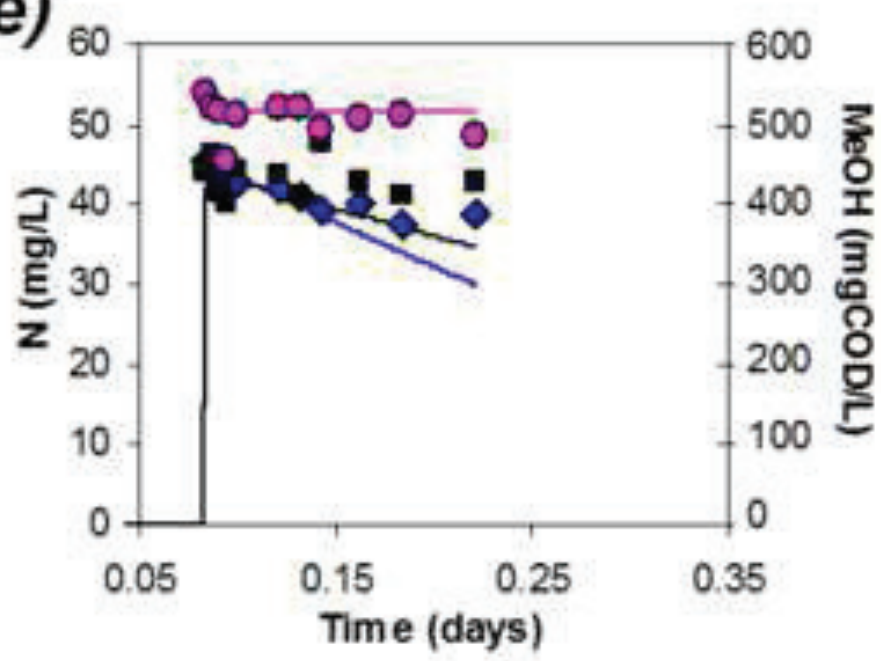

b)

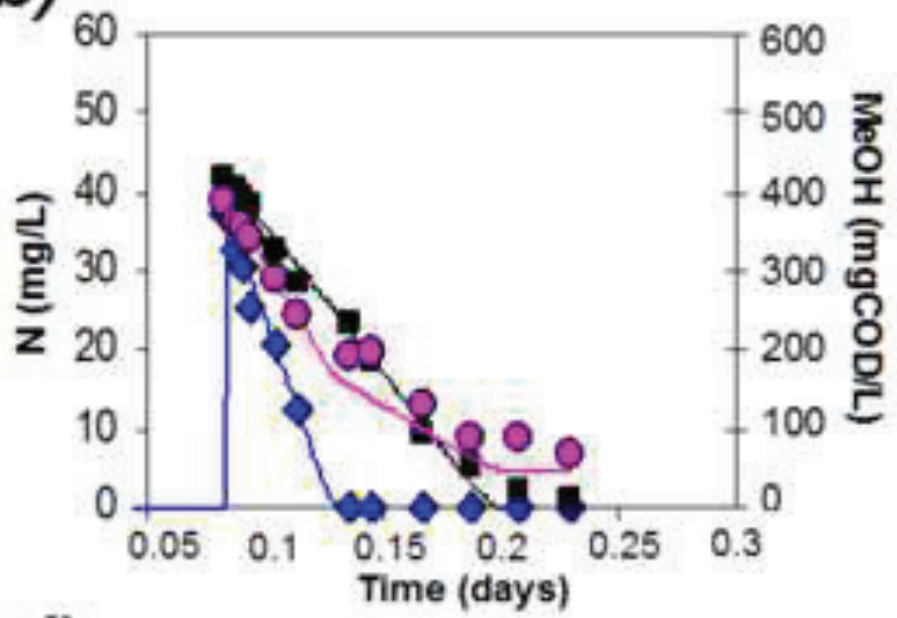

d)

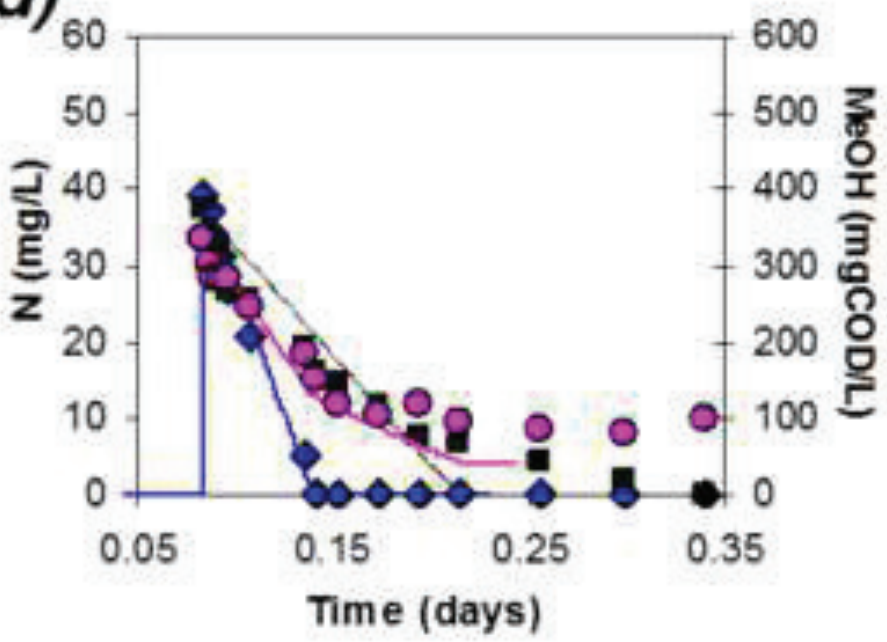




\section{Figure 4}

Click here to download high resolution image

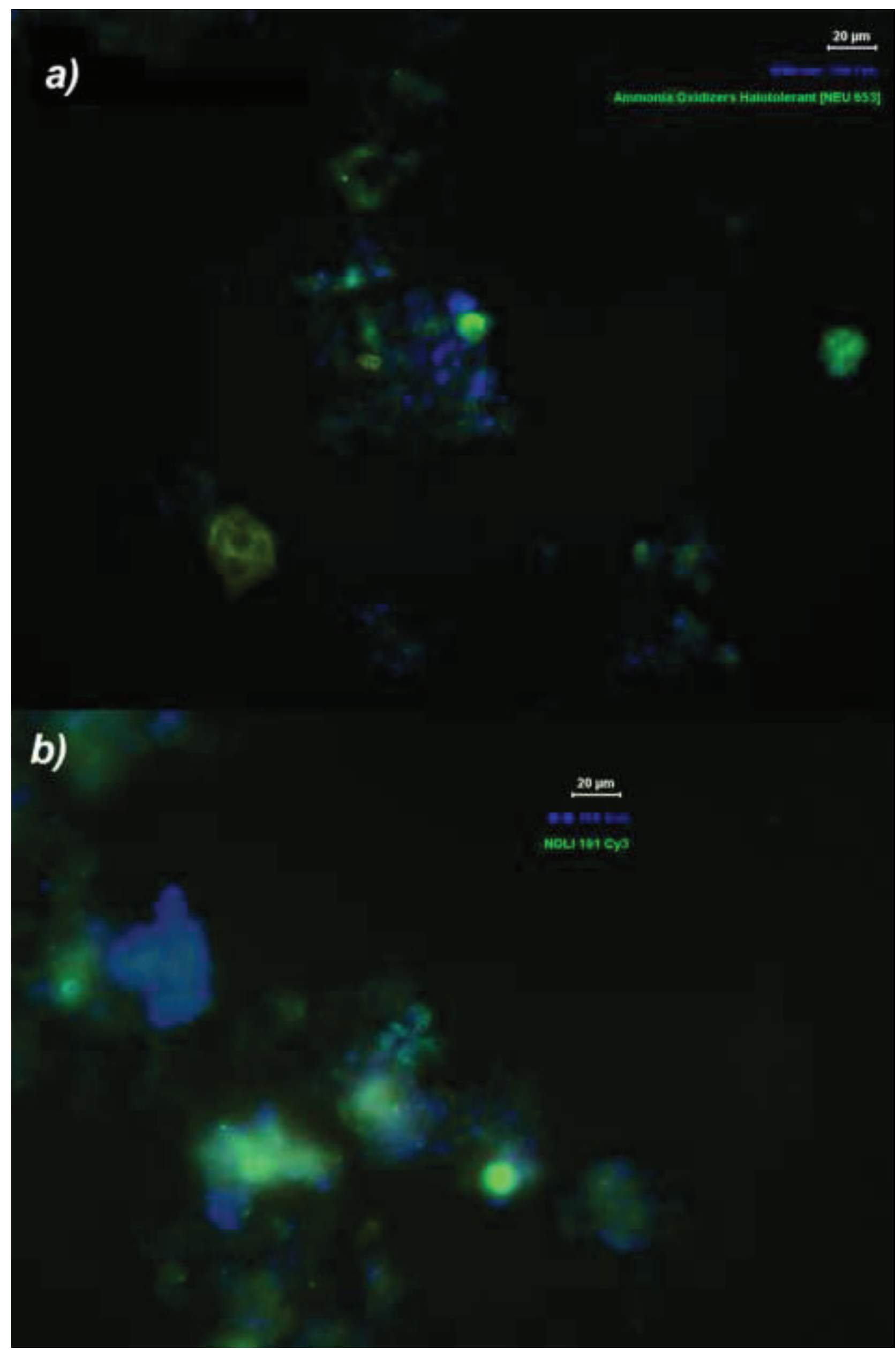


Supplementary Material
Click here to download St

Click here to download Supplementary Material: SUPPLEMENTARY MATERIAL.pdf 